\title{
HIV: Cell Binding and Entry
}

\author{
Craig B. Wilen ${ }^{1}$, John C. Tilton ${ }^{2}$, and Robert W. Doms ${ }^{1}$ \\ ${ }^{1}$ Department of Microbiology, University of Pennsylvania, Philadelphia, Pennsylvania 19104 \\ ${ }^{2}$ Department of General Medical Science, Center for Proteomics and Bioinformatics, Case Western \\ Reserve University, Cleveland, Ohio 44106 \\ Correspondence: doms@upenn.edu
}

The first step of the human immunodeficiency virus (HIV) replication cycle-binding and entry into the host cell_-plays a major role in determining viral tropism and the ability of HIV to degrade the human immune system. HIV uses a complex series of steps to deliver its genome into the host cell cytoplasm while simultaneously evading the host immune response. To infect cells, the HIV protein envelope (Env) binds to the primary cellular receptor CD4 and then to a cellular coreceptor. This sequential binding triggers fusion of the viral and host cell membranes, initiating infection. Revealing the mechanism of HIV entry has profound implications for viral tropism, transmission, pathogenesis, and therapeutic intervention. Here, we provide an overview into the mechanism of HIV entry, provide historical context to key discoveries, discuss recent advances, and speculate on future directions in the field.

\section{HIV ENTRY FUNDAMENTALS}

$\mathrm{H}^{2}$ IV entry, the first phase of the viral replication cycle, begins with the adhesion of virus to the host cell and ends with the fusion of the cell and viral membranes with subsequent delivery of the viral core into the cytoplasm. The intricate series of protein-protein interactions that ultimately results in virus infection can be divided into several phases, some of which are essential and others that may serve to modulate the efficiency of the process. First, virions must bind to the target cell, with this being mediated either by the viral envelope (Env) protein or host cell membrane proteins incorporated into the virion with any one of a number of various cell attachment factors. Attachment can be relatively nonspecific, with
Env interacting with negatively charged cellsurface heparan sulfate proteoglycans (Saphire et al. 2001), or can result from more specific interactions between Env and $\alpha 4 \beta 7$ integrin (Arthos et al. 2008; Cicala et al. 2009) or pattern recognition receptors such as dendritic cellspecific intercellular adhesion molecular 3grabbing non-integrin (DC-SIGN) (Geijtenbeek et al. 2000; reviewed in Ugolini et al. 1999). HIV attachment to the host cell via any of these factors likely brings Env into close proximity with the viral receptor CD4 and coreceptor, increasing the efficiency of infection (Fig. 1) (Orloff et al. 1991). However, attachment factors differ from receptors in that they are not essential, and although they augment infection in vitro, their physiologic role in vivo remains unclear.

Editors: Frederic D. Bushman, Gary J. Nabel, and Ronald Swanstrom

Additional Perspectives on HIV available at www.perspectivesinmedicine.org

Copyright (C) 2012 Cold Spring Harbor Laboratory Press; all rights reserved; doi: 10.1101/cshperspect.a006866

Cite this article as Cold Spring Harb Perspect Med 2012;2:a006866 
C.B. Wilen et al.

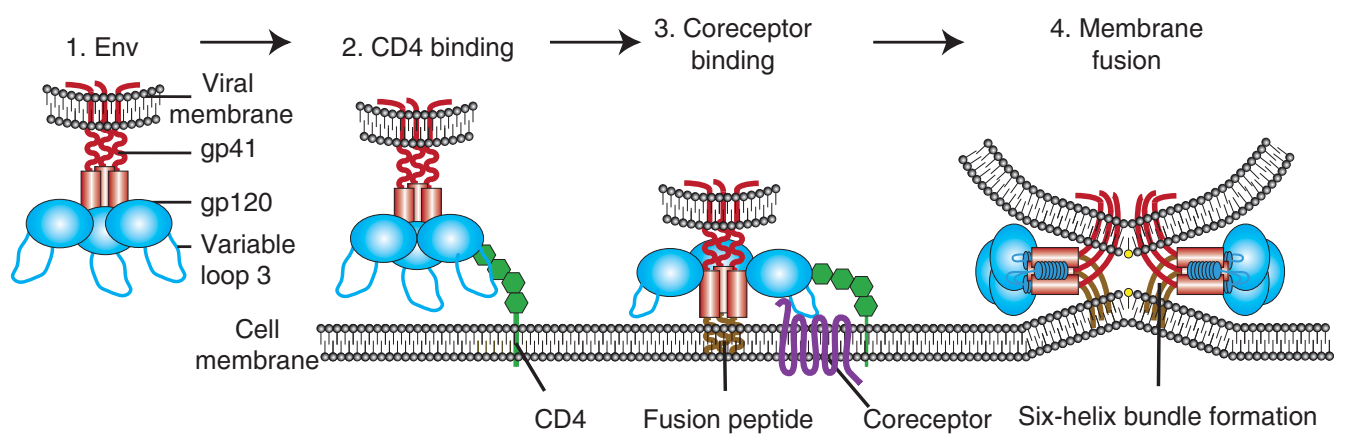

Figure 1. Overview of HIV entry. To deliver the viral payload into cells, HIV Env, comprised of gp120 and gp41 subunits (1), first attaches to the host cell, binding CD4 (2). This causes conformational changes in Env, allowing coreceptor binding, which is mediated in part by the V3 loop of Env (3). This initiates the membrane fusion process as the fusion peptide of gp 41 inserts into the target membrane, followed by six-helix bundle formation and complete membrane fusion (4).

The second step of virus entry and the first absolutely required for infection entails binding of Env to its primary receptor, the host protein CD4 (Maddon et al. 1986; McDougal et al. 1986). Env is a heavily glycosylated trimer of gp120 and gp41 heterodimers. The gp120 subunit is responsible for receptor binding and gp120 contains five relatively conserved domains (C1-C5) and five variable loops (V1V5), named for their relative genetic heterogeneity. Each of the variable regions is comprised of a loop structure formed by a disulfide bond at its base, with the exception of V5. The variable loops lie predominantly at the surface of gp120 and play critical roles in immune evasion and coreceptor binding, particularly the V3 loop (reviewed in Hartley et al. 2005). CD4 is a member of the immunoglobulin superfamily that normally functions to enhance T-cell receptor (TCR)-mediated signaling. Env interacts with the CD4 binding site (CD4bs) in gp120 (Kwong et al. 1998). Env binding to CD4 causes rearrangements of V1/V2 and subsequently V3. In addition, CD4 binding leads to formation of the bridging sheet, a four-stranded $\beta$ sheet comprised of two double-stranded $\beta$ sheets that are spatially separated in the unliganded state (Kwong et al. 1998; Chen et al. 2005). The bridging sheet and repositioned V3 loop play critical roles in the next step of virus entry, coreceptor engagement.
The third step of virus entry, coreceptor binding, is widely thought to be the trigger that activates the membrane fusion potential of Env. HIV strains can be broadly classified based on their coreceptor usage. Viruses that use the chemokine receptor CCR5 are termed R5 HIV, those that use CXCR4 are termed X4 $\mathrm{HIV}$, and viruses that can use both coreceptors are called R5X4 HIV (Berger et al. 1998). There is no compelling evidence that coreceptors other than CCR5 and CXCR4 play important roles in supporting infection of HIV-1 in vivo. With rare exception, only R5 and R5X4 viruses are transmitted between individuals (Keele et al. 2008), likely owing to multiple imperfect but overlapping host restrictions on X4 HIV transmission (reviewed in Margolis and Shattock 2006). Interestingly, despite identification at earlier time points and despite high levels of CXCR4 expression on circulating HIV target cells, X4 or even R5X4 HIV rarely predominate until late in infection (Tersmette et al. 1989; Schuitemaker et al. 1992; Connor et al. 1997). In addition, $\mathrm{X} 4$ viruses are less common in clade C HIV and SIV infection (Chen et al. 1998; Ping et al. 1999; Cecilia et al. 2000; Huang et al. 2007). Several nonmutually exclusive models may explain this. First, clade B Envs may be different in their ability to adapt to CXCR4 tropism. Second, there may be differences in clade B host biology. For instance, clade B hosts 
may have mitigated neutralizing antibody or cytotoxic $\mathrm{T}$ lymphocyte responses against X4 HIV compared with R5 HIV. Finally, clade B hosts most often live in developed countries and may face different environmental stresses including fewer or different chronic coinfections, which may increase target cell CCR5 expression. Elucidating the mechanism of coreceptor switch is a critical next step because it has implications for disease progression and therapy with HIV entry inhibitors.

A fourth step of virus entry is movement of the virus particle to the site where productive membrane fusion occurs. A series of recent studies has shown that a number of viruses usurp cellular transport pathways to reach specific destinations that are either needed for infection or that make entry more efficient, and that HIV might likewise use the host cell machinery to reach sites where membrane fusion can occur (Lehmann et al. 2005; Coyne and Bergelson 2006; Sherer et al. 2010). Some viruses have been shown to "surf" along the cell surface, moving from distal sites of attachment to more proximal regions of the cell body where virus entry occurs. Retroviruses, including HIV, have been shown to use this process on some cell lines (Lehmann et al. 2005; Sherer et al. 2010). In addition, HIV may need to be internalized by the host cell's endocytic machinery for productive membrane fusion to occur, as is discussed in a later section (Miyauchi et al. 2009).

The fifth and final step of virus entry is membrane fusion mediated by Env. Coreceptor binding induces exposure of the hydrophobic gp41 fusion peptide, which inserts into the host cell membrane. This tethers the viral and host membranes, allowing the fusion peptide of each gp41 in the trimer to fold at a hinge region, bringing an amino-terminal helical region (HR-N) and a carboxy-terminal helical region (HR-C) from each gp41 subunit together to form a six-helix bundle (6HB) (Chan et al. 1997; Weissenhorn et al. 1997). Because the HR-N domain is in close proximity to the host cell membrane owing to the fusion peptide, and the HR-C domain is in close proximity to the viral membrane owing to the gp41 transmembrane domain, formation of the $6 \mathrm{HB}$ is the driving force that brings the opposing membranes into close apposition, resulting in the formation of a fusion pore (reviewed in Melikyan 2008). Whether one or multiple HIV Env trimers are needed for complete membrane fusion is not yet clear. In summary, coreceptor binding unlocks the potential energy of the gp41 fusion complex resulting in $6 \mathrm{HB}$ formation, opening and stabilization of the membrane fusion pore, and subsequent delivery of the viral contents into the host cell cytoplasm.

\section{DISCOVERY OF THE HIV RECEPTORS}

In 1981, several years before the discovery of HIV, Gottlieb and colleagues (1981) reported $\mathrm{CD}^{+}{ }^{+} \mathrm{T}$-cell decline in four men who presented with pneumocystis pneumonia and mucosal candidiasis, among other opportunistic infections. Three years later, it was shown that HIV preferentially infects $\mathrm{CD} 4^{+} \mathrm{T}$ cells (Klatzmann et al. 1984) and that infection is potently inhibited by CD4-specific antibodies (reviewed in Sattentau and Weiss 1988). CD4 was then shown to coimmunoprecipitate with Env (McDougal et al. 1986) and CD4 expression could rescue infection in some nonpermissive cells (Maddon et al. 1986). However, CD4 transfection into mouse cells rescued binding of virus to the cell surface but not membrane fusion or virus infection, suggesting that there were other required cofactors (Maddon et al. 1986).

Although the discovery of CD4 as the primary HIV receptor occurred shortly after the onset of the epidemic, it took more than a decade to discover the first coreceptor. In 1993, CD26 was reported as the elusive HIV coreceptor (Callebaut et al. 1993); however, this was later disproved by several groups (Lazaro et al. 1994; Stamatatos and Levy 1994). In 1995, Feng and colleagues conclusively identified CXCR4 as a major HIV coreceptor by the use of an expression cloning strategy. A critical finding of this study was that CXCR4, then termed fusin, functioned as a coreceptor for what had been termed T-cell line tropic strains of HIV but not for virus strains that could infect human macrophages but that failed to enter T-cell lines 
(Feng et al. 1995, 1996). The seminal discovery of CXCR4 as a G-protein-coupled receptor (GPCR) in combination with the identification of the inhibitory effect of the $\beta$ chemokines CCL3 (MIP-1 $\alpha$ ), CCL4 (MIP1 $\beta$ ), and CCL5 (RANTES) (Cocchi et al. 1995) on some virus isolates led to the simultaneous and rapid discovery of CCR5 as the coreceptor for macrophage-tropic virus strains by five different groups (Alkhatib et al. 1996; Choe et al. 1996; Deng et al. 1996; Doranz et al. 1996; Dragic et al. 1996).

The importance of the viral coreceptors for HIV infection in vivo was shown by the discovery of a 32 base-pair deletion in ccr5, termed ccr5 $\Delta 32$, which has an allelic frequency of $\sim 10 \%$ in Caucasians (Dean et al. 1996; Liu et al. 1996; Samson et al. 1996). The $\Delta 32$ mutation results in a premature stop codon in the second extracellular loop of CCR5 and subsequent retention of the mutant protein in the endoplasmic reticulum. Homozygosity for this polymorphism results in profound resistance to HIV infection, although several $\Delta 32$ homozygotes have been infected with X4 viruses (Balotta et al. 1997; O'Brien et al. 1997; Theodorou et al. 1997). In addition, heterozygosity confers partial protection to infection (Dean et al. 1996; Samson et al. 1996) and disease progression (Dean et al. 1996; Huang et al. 1996).

Elucidating the mechanism of HIV entry has directly translated into therapeutic benefit. Currently, there are two FDA-approved entry inhibitors, enfuvirtide and maraviroc, whereas others are in various stages of development. In 2003, enfuvirtide became the first licensed entry inhibitor; it is a 36-residue-long peptide whose sequence is based on that of the HR-C in gp41. As a result, enfuvirtide behaves much like HR-C in that it binds to the HR-N prehairpin intermediate and inhibits $6 \mathrm{HB}$ formation and subsequent membrane fusion (Wild et al. 1992, 1993). Although enfuvirtide is a highly specific and effective membrane fusion inhibitor (Lalezari et al. 2003; Lazzarin et al. 2003), its use has been limited because it must be injected owing to its lack of oral bioavailability. Recently, protease-resistant D-peptide fusion inhibitors have been developed that also prevent $6 \mathrm{HB}$ formation, which may overcome this limitation (Eckert et al. 1999; Welch et al. 2007, 2010). In addition to enfuvirtide, the CCR5 inhibitor maraviroc has been approved for clinical use. Maraviroc is a small-molecule allosteric inhibitor that binds within the CCR5 transmembrane cavity resulting in conformational changes in the extracellular loop domains of the chemokine receptor that interact with Env (Dorr et al. 2005). Similar CCR5 small-molecule inhibitors are in various stages of testing (reviewed in Tilton and Doms 2009).

\section{KEY RECENT ADVANCES}

Our understanding of the HIV entry process is derived largely from structural and in vitro studies. As the field has evolved, there is now increased emphasis on placing the now rather well-understood membrane fusion reaction in a cellular context, asking where and when virus entry takes place as well as how virus particles are transferred between cells. Increased structural detail continues to provide insight into the entry process and suggests targets for smallmolecule inhibitors and neutralizing antibodies. Finally, attempts to recapitulate the ccr $5 \Delta 32$ phenotype have been developed with some being brought forward to early-stage clinical development (Perez et al. 2008).

\section{New Structural Information}

A full understanding of the HIV entry process requires detailed structural information. The structure of CD4 alone and in complex with a gp120 core fragment has been solved for HIV (Kwong et al. 1998; Huang et al. 2005) and simian immunodeficiency virus (SIV) (see online Movie 1 at www.perspectivesinmedicine.org) (Chen et al. 2005). The structure of the postfusion $6 \mathrm{HB}$ in gp41 has also been determined (see online Movie 2 at www.perspectivesinmedicine. org) (Chan et al. 1997; Weissenhorn et al. 1997). What has been lacking is a structure of the native Env trimer and the HIV coreceptors. However, $\mathrm{Wu}$ et al. (2010) recently described five independent structures of CXCR4 bound to two different small-molecule antagonists, which have 

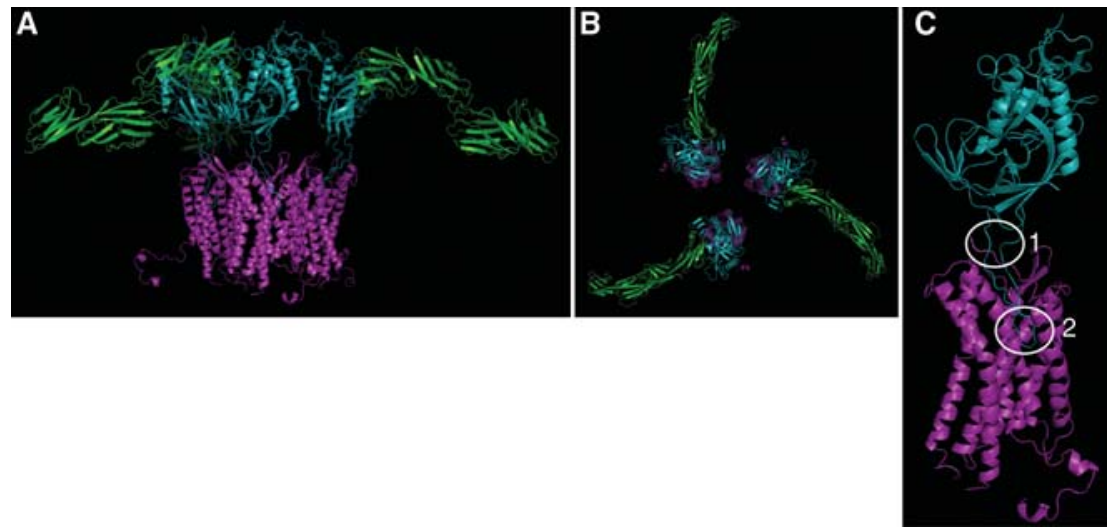

Figure 2. Model of gp120 engagement of CD4 and CXCR4. Recent structural studies have enhanced our understanding of the molecular interactions between gp120 (cyan) and its receptors. Here, CD4 (green) and CXCR4 (purple), shown as monomers for clarity, are shown simultaneously binding to gp120. (A) Lateral view. (B) Top view. However, the number of $\mathrm{CD} 4$ and coreceptor molecules required to interact with Env to mediate productive fusion remains unknown. (C) Gp120 has two key interactions with coreceptor. (1) The base of the V3 loop binds to the amino-terminal domain of the coreceptor, whereas the tip of the V3 loop binds to the second extracellular loop (ECL2). Although both interactions are important, viral strains differ on their dependency of each interaction. (Structural model generated by Wu et al. 2010.)

given insight into both the tertiary and quaternary structure of the native protein (Fig. 2). First, both chemokines and Env have been reported to engage CCR5 and CXCR4 in a twosite model with the chemokine receptor amino terminus as site one and the extracellular loops (ECLs), particularly ECL2, as site two. Although the orientation of the CXCR4 aminoterminal domain could not be solved owing to structural flexibility, the crystal structure provides high-resolution insight into the ECL2 binding site. Second, all five structures portray CXCR4 as a homodimer (see online Movie 3 at www.perspectivesinmedicine.org), which is consistent with biochemical studies that have suggested CXCR4 exists as an oligomer in the host cell membrane (Babcock et al. 2003). Although the implications of CXCR4 dimerization remain unclear for HIV infection, it may explain the dominant phenotype of a carboxyterminal CXCR4 human mutation that results in WHIM syndrome, which is characterized by warts, hypogammaglobulinemia, infections, and myelokathexis (retention of neutrophils in the bone marrow) (Hernandez et al. 2003). Finally, the identified homodimer interface may represent a novel CXCR4 or potentially
CCR5 drug target, because CCR5 and CXCR4 have been reported to heterodimerize in vivo (Sohy et al. 2007, 2009). Further structural studies are needed to better define the precise interactions of Env and coreceptor and to assess the mechanisms of signaling and heterodimerization with other chemokine receptors.

\section{Where Does Virus Entry Occur?}

The entry of viruses into cells is controlled in both time and space, with these parameters being regulated by host cell factors that serve to unlock the membrane fusion potential of viral membrane proteins. Many viruses require delivery by the host cell into an acidic, intracellular compartment where low $\mathrm{pH}$ triggers membrane-fusion-inducing conformational changes (reviewed in Marsh and Helenius 2006). HIV entry does not require low $\mathrm{pH}$; instead it is triggered by receptor engagement (Stein et al. 1987). The fact that HIV does not require low $\mathrm{pH}$ for cellular entry does not imply that fusion occurs at the cell surface. In fact, no spatial information is provided by the triggering mechanism. Despite this, it was often assumed that HIV fuses at the cell surface owing to several 
observations (reviewed in Uchil and Mothes 2009). First, Env expression on the cell surface can mediate cell-to-cell fusion, indicating not only that Env is the only viral membrane protein needed to elicit fusion but that low $\mathrm{pH}$ is clearly not required. Second, very early studies on HIV entry showed that lysomotropic agents, which increase endosomal $\mathrm{pH}$, do not inhibit HIV infection (McClure et al. 1988). Third, inhibiting endocytosis of CD4 in cell lines by mutating its cytoplasmic domain does not affect HIV infection (Maddon et al. 1988). Together, these studies show that HIV entry is not $\mathrm{pH}$ dependent, but they provide no definitive information as to whether fusion occurs at the cell surface or from within endocytic vesicles, albeit in a $\mathrm{pH}$-independent fashion.

The question of where HIV-membrane fusion occurs has recently been reexamined (Miyauchi et al. 2009). By combining lipid and content mixing assays with single virion fluorescent imaging, Miyauchi et al. tracked the location of virus membrane fusion in HeLa cells overexpressing CD4, CCR5, and CXCR4. They found that whereas lipid mixing can occur at the cell surface, content mixing only occurred in intracellular perinuclear compartments and thus concluded that complete fusion requires endocytosis. Whether this is always the case remains to be determined because the genetic variability of HIV and the diverse cell types it can infect make generalization difficult.

An interesting question is whether the site of entry matters; with regard to the use of entry inhibitors, probably not: Both coreceptor antagonists and fusion inhibitors block virus infection in vitro and in vivo, and neutralizing antibodies clearly function as well. However, the site of entry is more likely to have an impact on the likelihood of a productive infection actually occurring. For instance, after cellular attachment, HIV can actively surf along the cellular membrane from filopodia or microvilli to the cell body. This actin-dependent process requires receptor engagement and serves to enhance infection efficiency. Surfing toward the cell body may have several favorable consequences for the virus. First, it may facilitate endocytic HIV uptake. Second, it may bring the virus to a membrane region that has higher levels of coreceptor or important downstream signaling molecules (McDonald et al. 2003). Third, it may allow the fusion event to occur closer to the nucleus, which is the ultimate target of HIV. Thus, the site of initial HIV attachment is likely random; however, HIV hijacks the cellular machinery to traverse the cell membrane to a more favorable site of entry, be it at the plasma membrane or endosome, which ultimately serves to augment infection efficiency (Lehmann et al. 2005).

\section{Cell-Cell Transfer and the Virological Synapse}

In vitro, the rate-limiting step of virus infection is attachment to the host cell. In vivo, newly produced virions may well encounter an immediately adjoining, uninfected cell. In some cases, transfer of virus from one cell to another is a specialized process, as in the case of dendritic cells (DCs), which are professional antigenpresenting cells (APCs) that scavenge the periphery, sampling antigen. They are commonly found in the mucosa and thus may be encountered by HIV during transmission. On antigen binding, DCs migrate to the lymph nodes, process, and present the antigen to $\mathrm{T}$ cells to trigger an adaptive immune response. DCs are relatively resistant to productive HIV infection owing to a combination of low CD4 and coreceptor expression, host restriction factors, postintegration HIV transcription blocks, and other unknown factors (Bakri et al. 2001). However, they express a diverse range of attachment factors that facilitate the internalization and processing of pathogens before antigen presentation. HIV, along with viruses (Igakura et al. 2003; Yang et al. 2004), can take advantage of this pathway to augment infection efficiency and dissemination (Fig. 3) (reviewed in Piguet and Steinman 2007).

Cameron et al. (1992) first showed that DCs could catalyze HIV infection of cocultured $\mathrm{CD}^{+} \mathrm{T}$ cells without themselves getting productively infected. Each DC can bind up to several hundred virions (McDonald et al. 2003) most likely via a C-type lectin such as DC-SIGN 

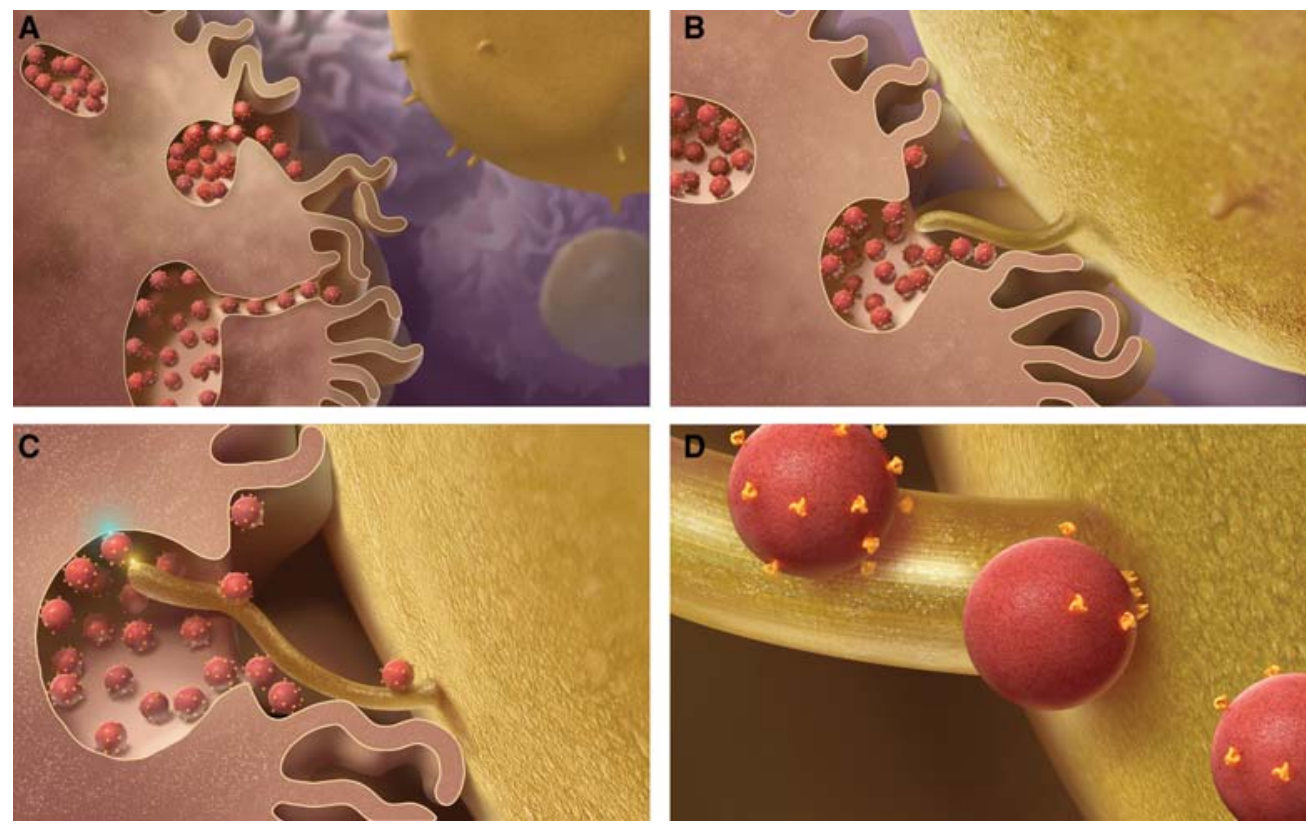

Figure 3. Model of DC-mediated transinfection of $\mathrm{CD} 4^{+} \mathrm{T}$ cells. $(A)$ DCs capture and concentrate virions in trypsin-resistant surface-accessible compartments. (B) $\mathrm{CD}^{+} \mathrm{T}$ cells, containing membrane protrusions, bind DCs. $(C)$ The $\mathrm{CD}^{+}{ }^{+}$T-cell protrusions invade the virus-containing compartments and efficiently bind HIV. (D) Virus then migrates toward the cell body to initiate infection. (Figure reproduced from Felts et al. 2010; reprinted, with permission, from Proceedings of the National Academy of Sciences (C) 2010.)

(Geijtenbeek et al. 2000; Turville et al. 2002). After binding, the virions are endocytosed into a trypsin-resistant compartment (Geijtenbeek et al. 2000), and then after DC binding to a $\mathrm{T}$ cell, internalized virus migrates to the DC:T-cell interface (McDonald et al. 2003) where it encounters the T-cell membrane forming the infectious synapse, analogous to the immunologic synapse that forms on MHCTCR binding (reviewed in Vasiliver-Shamis et al. 2010). In addition to efficiently concentrating and presenting HIV at the site of T-cell contact, the infectious synapse is characterized by recruitment of CD4, CCR5, and CXCR4.

Recent advances in electron microscopy have enabled 3D (three-dimensional)-structural studies of the infectious synapse that have shed light on this mechanism (Felts et al. 2010). DCs produce membranous protrusions that engulf the surrounding extracellular environment, trapping virions in a surface-accessible but protected compartment. It remains unclear as to whether this occurs before or after virion binding and whether it is Env induced. When $\mathrm{CD} 4^{+}$T cells contact DCs, they extend filopodia, enriched for CD4 and coreceptor, into the invaginated DC compartments that contain bound virions (Fig. 3). Together, the efficient binding of HIV, relocalization to the point of $\mathrm{CD} 4^{+}$ $\mathrm{T}$-cell contact, and the recruitment of the requisite HIV entry receptors promote HIV infection at the infectious synapse (McDonald et al. 2003; Hubner et al. 2009).

\section{A Novel Attachment Factor: $\alpha 4 \beta 7$ Integrin}

Although cell-to-cell transmission of HIV augments infection efficiency, the mechanism of virological synapse formation remains unclear. $\alpha 4 \beta 7$ integrin has been reported to bind gp 120; induce activation of LFA-1 $(\alpha \mathrm{L} \beta 2$ integrin), which contributes to formation of the immunologic synapse (reviewed in Bromley et al. 2001); and subsequently augment infection 
C.B. Wilen et al.

efficiency in vitro (Arthos et al. 2008; Cicala et al. 2009).

$\alpha 4 \beta 7$ is a heterodimeric protein comprised of an $\alpha 4$ and $\beta 7$ subunit that when expressed on $\mathrm{CD}^{+}{ }^{+} \mathrm{T}$ cells facilitates homing to the gut and other mucosal tissues. Its activation and expression are up-regulated by retinoic acid in vitro, which may also be locally secreted by mucosal DCs in vivo. The discovery of $\alpha 4 \beta 7$ as an attachment factor is of particular interest because HIV disrupts the integrity of the mucosal barrier and preferentially depletes gut $\mathrm{CD} 4^{+} \mathrm{T}$ cells, which are more activated and express higher levels of CCR5 than peripheral CD $4{ }^{+}$T cells. $\alpha 4 \beta 7$ is thought to bind an LDV (Leu-Asp-Val) tripeptide motif on the second variable loop (V2) of gp120, with this resulting in lymphocyte function-associated antigen 1 (LFA-1) activation. In addition, $\alpha 4 \beta 7$ colocalizes with CD4 and CCR5 at the virological synapse, which may further enhance infection. Blockade of $\alpha 4 \beta 7$ with monoclonal antibodies or a peptide delays replication of HIV in vitro, further supporting its role in HIV infection (Cicala et al. 2009). Future work is needed to assess whether there are protective effects of inhibiting HIV- $\alpha 4 \beta 7$ interactions in vivo, and to validate this novel attachment factor as a therapeutic target.

\section{FUTURE DIRECTIONS SIGNALING}

\section{Signal Transduction Mediated by HIV Env}

HIV Env has the capacity to mediate signal transduction cascades through CD4 and coreceptors, although the physiological importance on viral entry, replication, and pathogenesis remains controversial. Recent discoveries have provided evidence that signaling does play an important role under certain circumstances. In this section, we briefly review what is known about Env signaling through its receptor and coreceptors and highlight some of the recent discoveries in the field.

\section{Signal Transduction through CD4}

During encounters between $\mathrm{CD} 4^{+} \mathrm{T}$ cells and APCs, the CD4 molecule acts to enhance signaling through the TCR as it engages a cognate peptide bound to major histocompatibility complex class II (pMHC). Recruitment of the Src-family protein tyrosine kinase Lck to the immunological synapse through an interaction with the cytoplasmic tail of CD4 results in phosphorylation of immunoreceptor-tyrosine-based activation motifs (ITAMs) present on the CD3 $\gamma, \mathrm{CD} 3 \delta, \mathrm{CD} 3 \varepsilon$, and TCR- $\zeta$ subunits of the TCR complex and interactions with effector molecules (Love and Hayes 2010; Padhan and Varma 2010). Doubly phosphorylated ITAMs on the TCR- $\zeta$ subunit recruit the Sykfamily protein tyrosine kinase ZAP-70, which in turn phosphorylates the scaffold proteins LAT and SLP-76 that recruit many additional signaling proteins, eventually resulting in T-cell activation and proliferation (reviewed in Love and Hayes 2010).

Although HIV has been shown to signal through CD4 on binding (Hivroz et al. 1993; Briant et al. 1998) and to increase the activity of Lck (Juszczak et al. 1991), it remains unclear whether signaling is essential for infectivity. Although multiple early studies with truncated forms of CD4 indicated that signaling through CD4 was not required for HIV entry (Benkirane et al. 1994; Tremblay et al. 1994), most of these assays were performed on cell lines and using cell-free virus infection. Several more recent studies have shown a potential role for Env-CD4 signaling in the context of cell-cell spread at the infectious synapse, which as noted before is a specialized junction between cells that resembles the immunological synapse between APCs and T cells. One of the key features of the immunological synapse is that $\mathrm{T}$ cells stop migration through the lymph node or target tissue to allow sustained interaction with the APCs. HIV gp120 was able to arrest the migration of primary activated $\mathrm{CD}^{+}{ }^{+} \mathrm{T}$ cells in the presence of ICAM-1 and spontaneously induce the formation of a virological synapse (Vasiliver-Shamis et al. 2008). Signal transduction through CD4 and Lck were subsequently found to be responsible for depletion of cortical F-actin underneath the virological synapse using a planar membrane model system, allowing transfer of the viral core from the plasma membrane to the nucleus (Vasiliver-Shamis et al. 2009). These 
studies suggest that Env signaling through CD4 may play a role in HIV entry under physiological conditions.

\section{Signal Transduction through CCR5 and CXCR4}

CCR5 and CXCR4 are both members of the seven-transmembrane-spanning family of heterotrimeric GPCRs. This family of proteins is characterized by an extracellular aminoterminal domain, seven membrane-spanning domains that form three extracellular and three intracellular loops, and a cytoplasmic tail domain. The amino terminus (site one) and three ECLs (site two) together form the binding pocket for the cognate chemokines, which appear to attach to their receptor and transmit signals in a two-site binding process (reviewed in Clark-Lewis et al. 1995). The intracellular loops and cytoplasmic tail bind to the heterotrimeric $G$ proteins that in turn mediate effector functions.

The ability of HIV to signal through the chemokine receptors has been documented since shortly after their identification as coreceptors. Early studies tested the requirement for HIV to signal through coreceptor during entry into cells by inhibiting $\mathrm{G}_{\alpha \mathrm{i}}$ subunits through pertussis toxin (PTX) (Cocchi et al. 1996) or by creating chemokine mutants that abolished the ability to mobilize intracellular $\mathrm{Ca}^{2+}$, a key second messenger in signal transduction pathways (Alkhatib et al. 1997; Farzan et al. 1997; Gosling et al. 1997). Neither of these interventions blocked the ability of HIV to enter cells, leading to the conclusion that signaling was dispensable for viral infection and replication in target cells. During the next decade, a multitude of studies examined the requirement for coreceptor signaling during HIV entry, with sometimes contradictory results (reviewed in $\mathrm{Wu}$ and Yoder 2009). Often, experiments using cell lines or activated primary cells would indicate that signaling was not required for entry, whereas experiments with resting primary cells would indicate a role for signaling. Because the majority of $\mathrm{T}$ cells in lymphoid tissues are in resting or nondividing states-particularly before infection with HIV-examining the role for signaling under these conditions is particularly relevant.

Several recent studies have indicated that HIV depends on chemokine receptor signaling for efficient infection of target cells. First, Yoder and colleagues (2008) examined the ability of X4 HIV to infect resting $\mathrm{CD}^{+}{ }^{+} \mathrm{T}$ cells and found that HIV-mediated, $\mathrm{G}_{\alpha i}$ signaling through CXCR4 was required for entry. This pathway triggered the activation of a cellular actin-depolymerizing molecule, cofilin, altering cortical actin dynamics near the cell surface and facilitating viral fusion. Moreover, the study suggested a role for cofilin in movement of the viral preintegration complex (PIC) toward the nucleus. In contrast to the resting cell model used in this study, most activated and cycling $\mathrm{CD}^{+}{ }^{+} \mathrm{T}$ cells disassemble cortical actin without the requirement of cofilin. Although this study was limited to CXCR4 viral entry, activation of cofilin may also be required for CCR 5 viruses to enter resting, nondividing memory cells, such as the majority of $\mathrm{CD} 4{ }^{+} \mathrm{T}$ cells present in the lamina propria of the gut.

A second series of experiments from Harmon and colleagues (2010) showed that HIV also signals through the $G_{\alpha q}$ subunit, resulting in phospholipase $\mathrm{C}$ and Rac activation. Rac and the tyrosine kinase $\mathrm{Abl}$ then become linked to the Wave 2 complex through the adapter proteins Tiam-1 and IRSp53, promoting Arp2/ 3 -dependent actin nucleation and polymerization. Blocking activation of the Wave 2 complex with small interfering RNAs (siRNAs) or Abl kinase inhibitors arrested HIV entry at the hemifusion stage. Together, these experiments suggest a critical role for envelope-coreceptor signaling-induced actin remodeling during HIV entry, particularly in the case of resting $\mathrm{CD} 4^{+} \mathrm{T}$ cells.

The role of Env-mediated signaling through CD4 and coreceptor in the HIV entry process remains incompletely defined, but it appears increasingly likely that there are essential roles for signal transduction with physiologically relevant conditions and cell types. A common theme among these studies is the necessity for signaling in the reorganization of cytoskeletal 
C.B. Wilen et al.

actin, which may be involved in several key viral processes including "surfing," passage through the cortical actin barrier near the plasma membrane, and movement of the viral PIC into the nucleus.

\section{CONCLUDING REMARKS}

HIV entry is an active process that involves hijacking various components of the cellular machinery. Although Env engagement of CD4 and coreceptor are the most critical events of the entry process, viral surfing, endocytosis, cell-to-cell transmission, and receptor-mediated signaling likely play a role in enhancing infection efficiency by overcoming various host restrictions. Such factors likely affect the efficiency of transmission host cell tropism, and disease progression and are thus critical areas of future investigation. Although numerous questions remain, the most crucial is how can we better exploit our knowledge of HIV entry for therapeutic gain? Maraviroc and enfuvirtide have shown the efficacy of inhibiting entry, but novel therapeutic targets are needed and these likely represent the host molecules coopted by HIV.

\section{ACKNOWLEDGMENTS}

C.B.W., J.C.T., and R.W.D. were supported by grants T32 AI000632, F32 1F32AI077370, and R01 AI 040880, respectively. We thank Beili $\mathrm{Wu}$, Ray Stevens, and Sriram Subramaniam for the use of figures and PDB (Protein Data Bank) files.

\section{REFERENCES}

Alkhatib G, Combadiere C, Broder CC, Feng Y, Kennedy PE, Murphy PM, Berger EA. 1996. CC CKR5: A RANTES, MIP-1 $\alpha$, MIP- $1 \beta$ receptor as a fusion cofactor for macrophage-tropic HIV-1. Science 272: 1955-1958.

Alkhatib G, Locati M, Kennedy PE, Murphy PM, Berger EA 1997. HIV-1 coreceptor activity of CCR5 and its inhibition by chemokines: Independence from $\mathrm{G}$ protein signaling and importance of coreceptor downmodulation. Virology 234: 340-348.

Arthos J, Cicala C, Martinelli E, Macleod K, Van Ryk D, Wei D, Xiao Z, Veenstra TD, Conrad TP, Lempicki RA, et al. 2008. HIV-1 envelope protein binds to and signals through integrin $\alpha 4 \beta 7$, the gut mucosal homing receptor for peripheral T cells. Nat Immunol 9: 301-309.

Babcock GJ, Farzan M, Sodroski J. 2003. Ligand-independent dimerization of CXCR4, a principal HIV-1 coreceptor. J Biol Chem 278: 3378-3385.

Bakri Y, Schiffer C, Zennou V, Charneau P, Kahn E, Benjouad A, Gluckman JC, Canque B. 2001. The maturation of dendritic cells results in postintegration inhibition of HIV-1 replication. J Immunol 166: 3780-3788.

Balotta C, Bagnarelli P, Violin M, Ridolfo AL, Zhou D, Berlusconi A, Corvasce S, Corbellino M, Clementi M, Clerici M, et al. 1997. Homozygous $\Delta 32$ deletion of the CCR-5 chemokine receptor gene in an HIV-1-infected patient. AIDS 11: F67-F71.

Benkirane M, Jeang KT, Devaux C. 1994. The cytoplasmic domain of $\mathrm{CD} 4$ plays a critical role during the early stages of HIV infection in T-cells. EMBO J 13: 5559-5569.

Berger EA, Doms RW, Fenyo EM, Korber BT, Littman DR, Moore JP, Sattentau QJ, Schuitemaker H, Sodroski J, Weiss RA. 1998. A new classification for HIV-1. Nature 391: 240.

Briant L, Robert-Hebmann V, Acquaviva C, Pelchen-Matthews A, Marsh M, Devaux C. 1998. The protein tyrosine kinase p56lck is required for triggering NF- $\kappa \mathrm{B}$ activation upon interaction of human immunodeficiency virus type 1 envelope glycoprotein gp120 with cell surface CD4. J Virol 72: 6207-6214.

Bromley SK, Burack WR, Johnson KG, Somersalo K, Sims TN, Sumen C, Davis MM, Shaw AS, Allen PM, Dustin ML. 2001. The immunological synapse. Annu Rev Immunol 19: 375-396.

Callebaut C, Krust B, Jacotot E, Hovanessian AG. 1993. T cell activation antigen, CD26, as a cofactor for entry of HIV in $\mathrm{CD}^{+}$cells. Science 262: 2045-2050.

Cameron PU, Freudenthal PS, Barker JM, Gezelter S, Inaba K, Steinman RM. 1992. Dendritic cells exposed to human immunodeficiency virus type- 1 transmit a vigorous cytopathic infection to $\mathrm{CD} 4^{+}$T cells. Science 257: 383-387.

Cecilia D, Kulkarni SS, Tripathy SP, Gangakhedkar RR, Paranjape RS, Gadkari DA. 2000. Absence of coreceptor switch with disease progression in human immunodeficiency virus infections in India. Virology 271: 253-258.

Chan DC, Fass D, Berger JM, Kim PS. 1997. Core structure of gp41 from the HIV envelope glycoprotein. Cell 89: $263-273$.

Chen Z, Gettie A, Ho DD, Marx PA. 1998. Primary SIVsm isolates use the CCR5 coreceptor from sooty mangabeys naturally infected in West Africa: A comparison of coreceptor usage of primary SIVsm, HIV-2, and SIVmac. Virology 246: 113-124.

Chen B, Vogan EM, Gong H, Skehel JJ, Wiley DC, Harrison SC. 2005. Structure of an unliganded simian immunodeficiency virus gp120 core. Nature 433: 834-841.

Choe H, Farzan M, Sun Y, Sullivan N, Rollins B, Ponath PD, Wu L, Mackay CR, LaRosa G, Newman W, et al. 1996. The $\beta$-chemokine receptors CCR 3 and CCR5 facilitate infection by primary HIV-1 isolates. Cell 85: 1135-1148.

Cicala C, Martinelli E, McNally JP, Goode DJ, Gopaul R, Hiatt J, Jelicic K, Kottilil S, Macleod K, O’Shea A, et al. 2009. The integrin $\alpha 4 \beta 7$ forms a complex with cellsurface CD4 and defines a T-cell subset that is highly 
susceptible to infection by HIV-1. Proc Natl Acad Sci 106: 20877-20882.

Clark-Lewis I, Kim KS, Rajarathnam K, Gong JH, Dewald B, Moser B, Baggiolini M, Sykes BD. 1995. Structure-activity relationships of chemokines. J Leukoc Biol 57: 703-711.

Cocchi F, DeVico AL, Garzino-Demo A, Arya SK, Gallo RC, Lusso P. 1995. Identification of RANTES, MIP-1 $\alpha$, and MIP-1 $\beta$ as the major HIV-suppressive factors produced by $\mathrm{CD} 8^{+} \mathrm{T}$ cells. Science 270: $1811-1815$.

Cocchi F, DeVico AL, Garzino-Demo A, Cara A, Gallo RC, Lusso P. 1996. The V3 domain of the HIV-1 gp120 envelope glycoprotein is critical for chemokine-mediated blockade of infection. Nat Med 2: 1244-1247.

Connor RI, Sheridan KE, Ceradini D, Choe S, Landau NR. 1997. Change in coreceptor use correlates with disease progression in HIV-1-infected individuals. J Exp Med 185: $621-628$.

Coyne CB, Bergelson JM. 2006. Virus-induced Abl and Fyn kinase signals permit coxsackievirus entry through epithelial tight junctions. Cell 124: 119-131.

Dean M, Carrington M, Winkler C, Huttley GA, Smith MW, Allikmets R, Goedert JJ, Buchbinder SP, Vittinghoff E, Gomperts E, et al. 1996. Genetic restriction of HIV-1 infection and progression to AIDS by a deletion allele of the CKR5 structural gene. Hemophilia Growth and Development Study, Multicenter AIDS Cohort Study, Multicenter Hemophilia Cohort Study, San Francisco City Cohort, ALIVE Study. Science 273: 1856-1862.

Deng H, Liu R, Ellmeier W, Choe S, Unutmaz D, Burkhart M, Di Marzio P, Marmon S, Sutton RE, Hill CM, et al. 1996. Identification of a major co-receptor for primary isolates of HIV-1. Nature 381: 661-666.

Doranz BJ, Rucker J, Yi Y, Smyth RJ, Samson M, Peiper SC, Parmentier M, Collman RG, Doms RW. 1996. A dualtropic primary HIV-1 isolate that uses fusin and the $\beta$-chemokine receptors CKR-5, CKR-3, and CKR- $2 \mathrm{~b}$ as fusion cofactors. Cell 85: 1149-1158.

Dorr P, Westby M, Dobbs S, Griffin P, Irvine B, Macartney M, Mori J, Rickett G, Smith-Burchnell C, Napier C, et al. 2005. Maraviroc (UK-427,857), a potent, orally bioavailable, and selective small-molecule inhibitor of chemokine receptor CCR5 with broad-spectrum antihuman immunodeficiency virus type 1 activity. Antimicrob Agents Chemother 49: 4721-4732.

Dragic T, Litwin V, Allaway GP, Martin SR, Huang Y, Nagashima KA, Cayanan C, Maddon PJ, Koup RA, Moore JP, et al. 1996. HIV-1 entry into CD4 ${ }^{+}$cells is mediated by the chemokine receptor CC-CKR-5. Nature 381: 667-673.

Eckert DM, Malashkevich VN, Hong LH, Carr PA, Kim PS. 1999. Inhibiting HIV-1 entry: Discovery of D-peptide inhibitors that target the gp41 coiled-coil pocket. Cell 99: $103-115$.

Farzan M, Choe H, Martin KA, Sun Y, Sidelko M, Mackay CR, Gerard NP, Sodroski J, Gerard C. 1997. HIV-1 entry and macrophage inflammatory protein- $1 \beta$-mediated signaling are independent functions of the chemokine receptor CCR5. J Biol Chem 272: 6854-6857.

Felts RL, Narayan K, Estes JD, Shi D, Trubey CM, Fu J, Hartnell LM, Ruthel GT, Schneider DK, Nagashima K, et al. 2010. 3D visualization of HIV transfer at the virological synapse between dendritic cells and T cells. Proc Natl Acad Sci 107: 13336-13341.

Feng Y, Zhang F, Lokey LK, Chastain JL, Lakkis L, Eberhart D, Warren ST. 1995. Translational suppression by trinucleotide repeat expansion at FMR1. Science 268: 731734.

Feng Y, Broder CC, Kennedy PE, Berger EA. 1996. HIV-1 entry cofactor: Functional cDNA cloning of a seventransmembrane, G protein-coupled receptor. Science 272: $872-877$.

Geijtenbeek TB, Kwon DS, Torensma R, van Vliet SJ, van Duijnhoven GC, Middel J, Cornelissen IL, Nottet HS, KewalRamani VN, Littman DR, et al. 2000. DC-SIGN, a dendritic cell-specific HIV-1-binding protein that enhances trans-infection of T cells. Cell 100: 587-597.

Gosling J, Monteclaro FS, Atchison RE, Arai H, Tsou CL, Goldsmith MA, Charo IF. 1997. Molecular uncoupling of $\mathrm{C}$-C chemokine receptor 5-induced chemotaxis and signal transduction from HIV-1 coreceptor activity. Proc Natl Acad Sci 94: 5061-5066.

Gottlieb MS, Schroff R, Schanker HM, Weisman JD, Fan PT, Wolf RA, Saxon A. 1981. Pneumocystis carinii pneumonia and mucosal candidiasis in previously healthy homosexual men: Evidence of a new acquired cellular immunodeficiency. N Engl J Med 305: 1425-1431.

Harmon B, Campbell N, Ratner L. 2010. Role of Abl kinase and the Wave2 signaling complex in HIV-1 entry at a post-hemifusion step. PLoS Pathog 6: e1000956. doi: 10.1371/journal.ppat.1000956

Hartley O, Klasse PJ, Sattentau QJ, Moore JP. 2005. V3: HIV's switch-hitter. AIDS Res Hum Retroviruses 21: 171-189.

Hernandez PA, Gorlin RJ, Lukens JN, Taniuchi S, Bohinjec J, Francois F, Klotman ME, Diaz GA. 2003. Mutations in the chemokine receptor gene CXCR4 are associated with WHIM syndrome, a combined immunodeficiency disease. Nat Genet 34: 70-74.

Hivroz C, Mazerolles F, Soula M, Fagard R, Graton S, Meloche S, Sekaly RP, Fischer A. 1993. Human immunodeficiency virus gp120 and derived peptides activate protein tyrosine kinase p56lck in human CD4 T lymphocytes. Eur J Immunol 23: 600-607.

Huang Y, Paxton WA, Wolinsky SM, Neumann AU, Zhang L, He T, Kang S, Ceradini D, Jin Z, Yazdanbakhsh K, et al. 1996. The role of a mutant CCR5 allele in HIV-1 transmission and disease progression. Nat Med 2: 1240-1243.

Huang CC, Tang M, Zhang MY, Majeed S, Montabana E, Stanfield RL, Dimitrov DS, Korber B, Sodroski J, Wilson IA, et al. 2005. Structure of a V3-containing HIV-1 gp120 core. Science 310: 1025-1028.

Huang W, Eshleman SH, Toma J, Fransen S, Stawiski E, Paxinos EE, Whitcomb JM, Young AM, Donnell D, Mmiro F, et al. 2007. Coreceptor tropism in human immunodeficiency virus type 1 subtype D: High prevalence of CXCR4 tropism and heterogeneous composition of viral populations. J Virol 81: 7885-7893.

Hubner W, McNerney GP, Chen P, Dale BM, Gordon RE, Chuang FY, Li XD, Asmuth DM, Huser T, Chen BK. 2009. Quantitative 3D video microscopy of HIV transfer across T cell virological synapses. Science 323: $1743-$ 1747. 


\section{C.B. Wilen et al.}

Igakura T, Stinchcombe JC, Goon PK, Taylor GP, Weber JN Griffiths GM, Tanaka Y, Osame M, Bangham CR. 2003. Spread of HTLV-I between lymphocytes by virusinduced polarization of the cytoskeleton. Science 299: $1713-1716$.

Juszczak RJ, Turchin H, Truneh A, Culp J, Kassis S. 1991. Effect of human immunodeficiency virus gp120 glycoprotein on the association of the protein tyrosine kinase p56lck with CD4 in human T lymphocytes. J Biol Chem 266: 11176-11183.

Keele BF, Giorgi EE, Salazar-Gonzalez JF, Decker JM, Pham KT, Salazar MG, Sun C, Grayson T, Wang S, Li H, et al. 2008. Identification and characterization of transmitted and early founder virus envelopes in primary HIV-1 infection. Proc Natl Acad Sci 105: 7552-7557.

Klatzmann D, Barre-Sinoussi F, Nugeyre MT, Danquet C, Vilmer E, Griscelli C, Brun-Veziret F, Rouzioux C, Gluckman JC, Chermann JC, et al. 1984. Selective tropism of lymphadenopathy associated virus (LAV) for helperinducer T lymphocytes. Science 225: 59-63.

Kwong PD, Wyatt R, Robinson J, Sweet RW, Sodroski J, Hendrickson WA. 1998. Structure of an HIV gp120 envelope glycoprotein in complex with the CD4 receptor and a neutralizing human antibody. Nature 393: 648-659.

Lalezari JP, Henry K, O'Hearn M, Montaner JS, Piliero PJ, Trottier B, Walmsley S, Cohen C, Kuritzkes DR, Eron JJ, et al. 2003. Enfuvirtide, an HIV-1 fusion inhibitor, for drug-resistant HIV infection in North and South America. N Engl J Med 348: 2175-2185.

Lazaro I, Naniche D, Signoret N, Bernard AM, Marguet D, Klatzmann D, Dragic T, Alizon M, Sattentau Q. 1994. Factors involved in entry of the human immunodeficiency virus type 1 into permissive cells: Lack of evidence of a role for CD26. J Virol 68: 6535-6546.

Lazzarin A, Clotet B, Cooper D, Reynes J, Arasteh K, Nelson M, Katlama C, Stellbrink HJ, Delfraissy JF, Lange J, et al. 2003. Efficacy of enfuvirtide in patients infected with drug-resistant HIV-1 in Europe and Australia. N Engl J Med 348: 2186-2195.

Lehmann MJ, Sherer NM, Marks CB, Pypaert M, Mothes W. 2005. Actin- and myosin-driven movement of viruses along filopodia precedes their entry into cells. J Cell Biol 170: 317-325.

Liu R, Paxton WA, Choe S, Ceradini D, Martin SR, Horuk R, MacDonald ME, Stuhlmann H, Koup RA, Landau NR. 1996. Homozygous defect in HIV-1 coreceptor accounts for resistance of some multiply-exposed individuals to HIV-1 infection. Cell 86: 367-377.

Love PE, Hayes SM. 2010. ITAM-mediated signaling by the T-cell antigen receptor. Cold Spring Harb Perspect Biol doi: $10.1101 /$ cshperspect.a002485.

Maddon PJ, Dalgleish AG, McDougal JS, Clapham PR, Weiss RA, Axel R. 1986. The T4 gene encodes the AIDS virus receptor and is expressed in the immune system and the brain. Cell 47: 333-348.

Maddon PJ, McDougal JS, Clapham PR, Dalgleish AG, Jamal S, Weiss RA, Axel R. 1988. HIV infection does not require endocytosis of its receptor, CD4. Cell 54: 865-874.

Margolis L, Shattock R. 2006. Selective transmission of CCR5-utilizing HIV-1: The "gatekeeper" problem resolved? Nat Rev Microbiol 4: 312-317.
Marsh M, Helenius A. 2006. Virus entry: Open sesame. Cell 124: $729-740$.

McClure MO, Marsh M, Weiss RA. 1988. Human immunodeficiency virus infection of CD4-bearing cells occurs by a pH-independent mechanism. EMBO J 7: 513-518.

McDonald D, Wu L, Bohks SM, KewalRamani VN, Unutmaz D, Hope TJ. 2003. Recruitment of HIV and its receptors to dendritic cell-T cell junctions. Science 300: $1295-$ 1297.

McDougal JS, Kennedy MS, Sligh JM, Cort SP, Mawle A, Nicholson JK. 1986. Binding of HTLV-III/LAV to T4 ${ }^{+}$ $\mathrm{T}$ cells by a complex of the $110 \mathrm{~K}$ viral protein and the T4 molecule. Science 231: 382-385.

Melikyan GB. 2008. Common principles and intermediates of viral protein-mediated fusion: The HIV-1 paradigm. Retrovirology 5: 111.

Miyauchi K, Kim Y, Latinovic O, Morozov V, Melikyan GB 2009. HIV enters cells via endocytosis and dynamindependent fusion with endosomes. Cell 137: 433-444.

O’Brien TR, Winkler C, Dean M, Nelson JA, Carrington M, Michael NL, White GC II. 1997. HIV-1 infection in a man homozygous for CCR5 $\Delta 32$. Lancet 349: 1219.

Orloff GM, Orloff SL, Kennedy MS, Maddon PJ, McDougal JS. 1991. Penetration of CD4 T cells by HIV-1. The CD4 receptor does not internalize with HIV, and CD4-related signal transduction events are not required for entry. $J$ Immunol 146: 2578-2587.

Padhan K, Varma R. 2010. Immunological synapse: A multiprotein signalling cellular apparatus for controlling gene expression. Immunology 129: 322-328.

Perez EE, Wang J, Miller JC, Jouvenot Y, Kim KA, Liu O, Wang N, Lee G, Bartsevich VV, Lee YL, et al. 2008. Establishment of HIV-1 resistance in $\mathrm{CD} 4^{+} \mathrm{T}$ cells by genome editing using zinc-finger nucleases. Nat Biotechnol 26: $808-816$.

Piguet V, Steinman RM. 2007. The interaction of HIV with dendritic cells: Outcomes and pathways. Trends Immunol 28: $503-510$.

Ping LH, Nelson JA, Hoffman IF, Schock J, Lamers SL, Goodman M, Vernazza P, Kazembe P, Maida M, Zimba $\mathrm{D}$, et al. 1999. Characterization of V3 sequence heterogeneity in subtype $\mathrm{C}$ human immunodeficiency virus type 1 isolates from Malawi: Underrepresentation of X4 variants. J Virol 73: 6271-6281.

Samson M, Libert F, Doranz BJ, Rucker J, Liesnard C, Farber CM, Saragosti S, Lapoumeroulie C, Cognaux J, Forceille C, et al. 1996. Resistance to HIV-1 infection in caucasian individuals bearing mutant alleles of the CCR- 5 chemokine receptor gene. Nature 382: 722-725.

Saphire AC, Bobardt MD, Zhang Z, David G, Gallay PA. 2001. Syndecans serve as attachment receptors for human immunodeficiency virus type 1 on macrophages. J Virol 75: 9187-9200.

Sattentau QJ, Weiss RA. 1988. The CD4 antigen: Physiological ligand and HIV receptor. Cell 52: 631-633.

Schuitemaker H, Koot M, Kootstra NA, Dercksen MW, de Goede RE, van Steenwijk RP, Lange JM, Schattenkerk JK, Miedema F, Tersmette M. 1992. Biological phenotype of human immunodeficiency virus type 1 clones at different stages of infection: Progression of disease is associated 
with a shift from monocytotropic to T-cell-tropic virus population. J Virol 66: 1354-1360.

Sherer NM, Jin J, Mothes W. 2010. Directional spread of surface-associated retroviruses regulated by differential virus-cell interactions. J Virol 84: 3248-3258.

Sohy D, Parmentier M, Springael JY. 2007. Allosteric transinhibition by specific antagonists in CCR2/ CXCR4 heterodimers. J Biol Chem 282: 30062-30069.

Sohy D, Yano H, de Nadai P, Urizar E, Guillabert A, Javitch JA, Parmentier M, Springael JY. 2009. Hetero-oligomerization of CCR2, CCR5, and CXCR4 and the protean effects of "selective" antagonists. J Biol Chem 284: 31270-31279.

Stamatatos L, Levy JA. 1994. CD26 is not involved in infection of peripheral blood mononuclear cells by HIV-1. AIDS 8: $1727-1728$.

Stein BS, Gowda SD, Lifson JD, Penhallow RC, Bensch KG, Engleman EG. 1987. pH-independent HIV entry into CD4-positive T cells via virus envelope fusion to the plasma membrane. Cell 49: 659-668.

Tersmette M, Gruters RA, de Wolf F, de Goede RE, Lange JM, Schellekens PT, Goudsmit J, Huisman HG, Miedema F 1989. Evidence for a role of virulent human immunodeficiency virus (HIV) variants in the pathogenesis of acquired immunodeficiency syndrome: Studies on sequential HIV isolates. J Virol 63: 2118-2125.

Theodorou I, Meyer L, Magierowska M, Katlama C, Rouzioux C. 1997. HIV-1 infection in an individual homozygous for CCR5 $\Delta 32$. Seroco Study Group. Lancet 349: 1219-1220.

Tilton JC, Doms RW. 2009. Entry inhibitors in the treatment of HIV-1 infection. Antiviral Res 85: 91-100.

Tremblay M, Meloche S, Gratton S, Wainberg MA, Sekaly RP. 1994. Association of p56lck with the cytoplasmic domain of CD4 modulates HIV-1 expression. EMBO J 13: $774-783$.

Turville SG, Cameron PU, Handley A, Lin G, Pohlmann S, Doms RW, Cunningham AL. 2002. Diversity of receptors binding HIV on dendritic cell subsets. Nat Immunol 3: 975-983.

Uchil PD, Mothes W. 2009. HIV entry revisited. Cell 137: 402-404.

Ugolini S, Mondor I, Sattentau QJ. 1999. HIV-1 attachment Another look. Trends Microbiol 7: 144-149.

Vasiliver-Shamis G, Tuen M, Wu TW, Starr T, Cameron TO, Thomson R, Kaur G, Liu J, Visciano ML, Li H, et al. 2008. Human immunodeficiency virus type 1 envelope gp120 induces a stop signal and virological synapse formation in noninfected CD4 ${ }^{+}$T cells. J Virol 82: 9445-9457.

Vasiliver-Shamis G, Cho MW, Hioe CE, Dustin ML. 2009. Human immunodeficiency virus type 1 envelope gp120-induced partial T-cell receptor signaling creates an F-actin-depleted zone in the virological synapse. $J$ Virol 83: 11341-11355.

Vasiliver-Shamis G, Dustin ML, Hioe CE. 2010. HIV-1 virological synapse is not simply a copycat of the immunological synapse. Viruses 2: 1239-1260.

Weissenhorn W, Dessen A, Harrison SC, Skehel JJ, Wiley DC. 1997. Atomic structure of the ectodomain from HIV-1 gp41. Nature 387: 426-430.

Welch BD, VanDemark AP, Heroux A, Hill CP, Kay MS 2007. Potent D-peptide inhibitors of HIV-1 entry. Proc Natl Acad Sci 104: 16828-16833.

Welch BD, Francis JN, Redman JS, Paul S, Weinstock MT, Reeves JD, Lie YS, Whitby FG, Eckert DM, Hill CP, et al. 2010. Design of a potent D-peptide HIV-1 entry inhibitor with a strong barrier to resistance. J Virol 84: 11235-11244.

Wild C, Oas T, McDanal C, Bolognesi D, Matthews T. 1992. A synthetic peptide inhibitor of human immunodeficiency virus replication: Correlation between solution structure and viral inhibition. Proc Natl Acad Sci 89: 10537-10541.

Wild C, Greenwell T, Matthews T. 1993. A synthetic peptide from HIV-1 gp41 is a potent inhibitor of virusmediated cell-cell fusion. AIDS Res Hum Retroviruses 9: 1051-1053.

Wu Y, Yoder A. 2009. Chemokine coreceptor signaling in HIV-1 infection and pathogenesis. PLoS Pathog 5: e1000520. doi: 10.1371/journal.ppat.1000520.

Wu B, Chien EY, Mol CD, Fenalti G, Liu W, Katritch V, Abagyan R, Brooun A, Wells P, Bi FC, et al. 2010. Structures of the CXCR4 chemokine GPCR with smallmolecule and cyclic peptide antagonists. Science 330: 1066-1071.

Yang ZY, Huang Y, Ganesh L, Leung K, Kong WP, Schwartz O, Subbarao K, Nabel GJ. 2004. pH-dependent entry of severe acute respiratory syndrome coronavirus is mediated by the spike glycoprotein and enhanced by dendritic cell transfer through DC-SIGN. J Virol 78: 5642-5650.

Yoder A, Yu D, Dong L, Iyer SR, Xu X, Kelly J, Liu J, Wang W, Vorster PJ, Agulto L, et al. 2008. HIV envelope-CXCR4 signaling activates cofilin to overcome cortical actin restriction in resting CD4 T cells. Cell 134: 782-792. 


\section{$\&_{\mathrm{CSH}}^{\infty} \&$ Cold Spring Harbor

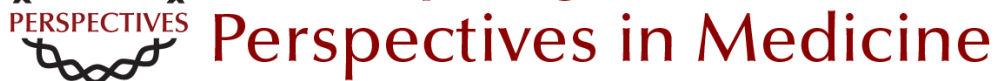

\section{HIV: Cell Binding and Entry}

Craig B. Wilen, John C. Tilton and Robert W. Doms

Cold Spring Harb Perspect Med 2012; doi: 10.1101/cshperspect.a006866 originally published online April 10, 2012

\section{Subject Collection HIV}

HIV Pathogenesis: Dynamics and Genetics of

Viral Populations and Infected Cells John Coffin and Ronald Swanstrom

Human Immunodeficiency Virus Vaccine Trials Robert J. O'Connell, Jerome H. Kim, Lawrence Corey, et al.

HIV Transmission George M. Shaw and Eric Hunter

Novel Cell and Gene Therapies for HIV James A. Hoxie and Carl H. June

\section{Behavioral and Biomedical Combination}

Strategies for HIV Prevention Linda-Gail Bekker, Chris Beyrer and Thomas C. Quinn

HIV-1 Assembly, Budding, and Maturation Wesley I. Sundquist and Hans-Georg Kräusslich

HIV-1 Assembly, Budding, and Maturation Wesley I. Sundquist and Hans-Georg Kräusslich

Lessons in Nonhuman Primate Models for AIDS Vaccine Research: From Minefields to Milestones Jeffrey D. Lifson and Nancy L. Haigwood
HIV-1 Pathogenesis: The Virus

Ronald Swanstrom and John Coffin

The T-Cell Response to HIV Bruce Walker and Andrew McMichael

HIV-1 Reverse Transcription Wei-Shau Hu and Stephen H. Hughes

HIV Pathogenesis: The Host A.A. Lackner, Michael M. Lederman and Benigno Rodriguez

HIV: Cell Binding and Entry Craig B. Wilen, John C. Tilton and Robert W. Doms

Innate Immune Control of HIV Mary Carrington and Galit Alter

HIV DNA Integration Robert Craigie and Frederic D. Bushman

HIV-1-Related Central Nervous System Disease: Current Issues in Pathogenesis, Diagnosis, and Treatment Serena Spudich and Francisco González-Scarano

For additional articles in this collection, see http://perspectivesinmedicine.cshlp.org/cgi/collection/ 